\section{MAST CELLS}

The Mast Cells

By Dr. Hans Selye. Pp. xxix +498 . (Washington, D.C.: Butterworth, Ine.; London: Butterworth and Co. (Publishers), Ltd., 1965.) 135s.

GIR ERNEST KENNAWAY once observed that $S$ "cancor research is tending to become buried under its own literature". Similar thoughts about the mast coll woro ovidently in the mind of Prof. Selye of Montreal when he set out to review, in T'he Mast Cells, an expanding literature already comprising some 2,500 titles. The treatment is novel -..'a book within a book'. Each chapter. and major sub-division opons in largo typo: collectively, these portions of the book form a running narrative, unencumbered by referencos, though logitimatoly coloured by the views and experience of the author. The remainder of the text, in smaller type, is made up of brisk, telegraphic ubstracts of tho pertinent litoraturo. A numbered code guidos the reader thence to a full bibliography. The final index is printed on tinted paper. Every aspect of the mast cell is dealt with. The rosult is superb.

Thoro are two types of mast cell, both discoverod by Paul Ehrlich early in his career. Tho first is the tissue mast cell which develops, diss and, as many believe, has its function, in the connective tissue. The second is the basophil (blood mast coll or mast loucocyte) the origin of which is in the bone marrow and the habitat of which is the periphoral blood. Both types of mast coll claborate cytoplasmic granules which stain metachromatically with various basic dyes. 'They were named Mastzellen in the belief that their granules form under conditions of hypernutrition (mästen, to fatten).

Sixty years aftor Fhrlich's discovory, Scandinavian workers gave to the mast coll its first plausible function. They woro soeking a cellular location for tho poworful anticoagulant, hoparin, and found it, in tho motachromatic granules of the tissue mast coll. Fifteen years later it was shown, by us, in Scotland, that the mast cell is as rich in histamine as it is in heparin. This stimulated intensive investigation on the modo of action of the newly discovorod histamine-liberators. There was more to come. Amorican workers then dernonstrated 5-hydroxytrypt. amine in the mast cells of mouse and rat. All those pharmacologically active agents are synthesized and stored within the mast cell. The mast granules are also curiously rich in protease and contain smaller amounts of other enzymos. Rocent observations suggest that catecholamines may be present in certain types of mast coll. For long the mast cell lacked a function. Now it has too many. 'This is a baffling situation for tho investigator: the newcomer, especially, looks for guidance.

Prof. Selye's book supplies his needs. There have been reviews in the past, of which, perhaps, Michels's brilliant chapter in Downey's Haematology (1938, and reprinted as part of a mast-cell symposium, Ann. N.Y. Acad. Sci., 103,491 ; 1963) romains outstanding. Spocialized monographs are available on heparin, histamine, hyaluronic acid, histochemistry, mast cells and lymphocytes, mast cells and anaphylaxis, the basophil-there are many excellent shorter surveys. Selye has out-reviewed us all. For the moment the mast coll has been brought withix tho compass of the individual.

Armed with this lavish compondium tho roador can soo at a glance where knowledge is well advanced and where gaps romain. Short chapter's on history, definition and terminology are followed by a long chapter on histology, including histochemistry. Embryology, a mere two pages, could already be profitably expanded by the inclusion of recent work by Burton (Anat. Rec., 150, 265; 1964) and Combs, Lagunoff and Benditt (J. Cell Biol., 25, $577 ; 1965)$. Likewise, the next soction on comparative anatomy could usefully draw on the comprohensivo survey by Grünborg and Kaiser (Zbl. f. Veterinärm., 11,
$729 ; 1964 ; 12,18 ; 1965)$. The longest chapter, "Agents Affecting Mast Cells", includes a detailed account of Prof. Solyo's own contribution to tho mast-coll story: 'calciphylaxis' implies the deposition of calcium, often massive, around mast colls or their products in hypercalcaemic rats; 'calcorgy' denotes a somowhat similar calcification in normal rats previously injected with certain metals. Calciphylaxis was itself tho subject of a considerable monograph by P'rof. Selye some three years ago. Excellent chapters then deal with the diseases of the mast-cell system, the mastocytosos and mast-coll dormatoses in man, and the mastocytomas in animals. The samo thorough troatment loads through biochemistry and the blood basophil to theories. Here, though many points of view are considered, tho reader will seek in vain for a hypothesis to cover all mast cells in all species.

Heparin can certainly be extracted chemically from mast cells, yet there is little to suggest a physiological roloaso of hoparin into tho blood: in somo quartors tho mucopolysaccharide is now regarded more as a structural component of the granule than a potential secretion. Histamino is undoubiodly synthesized and storod in mast cells, and is easily released. However, one would question the statemont (p. 366) that "virtually tho wholo histidinedecarboxylase activity of the body is concentrated in mast cells": even the specific enzyme $(p H$ 6.5 and sole substrate, histidine) has a wider distribution. 5-hydroxy tryptamine (serotonin) is restricted to the mast cells of mouse and rat. Calciphylaxis and calcergy have likewise as yot been demonstrated only in the rat: one has soon nothing like them in mice or men.

In the ond, Prof. Solyo ("Ovorvicw", p. 403) is driven to conelude that "the mast cell is a pluripotent cell, a kind of 'ernergency kit' which contains a number of compounds that tissues may need, especially in rogions exposed to local stress". This would certainly find more favour with me, as I havo myself been advocating a local 'mast-coll cycle', intermittent in action and motivated by trauma, for the past dozen years (Lancet, i, 841; 1954). Perhaps the roal 'emergoncy kit' is tho book itsolf. No futuro explorer on the mast-cell trail can afford to travel without it. Author and publisher alike are to be congratulated on a splendid achievement. James F. Rruex

\section{BONE}

\section{Proceedings of the Second European Symposium on Calcified Tissues}

ITold at the Domaine Provincial de Wegimont, Maroh 31st-April 4th, 1964. Edited by L. J. Richelle and M. J. Dallomagne. Pp. $\mathrm{xv}+471$. (Liège: Univeraité de Liège, 1965.) n.p.

CALCIFIED Tissues contains forty-six contributions on cell differentiation, fluorino, bone remodelling, collagen and kinetics of bone metabolism. It opens with a paper by Prof. F. C. McLean, the recognized doyen of osteology, summarizing some of the progress made in recent years towards the understanding of the mechanism of internal bono romodelling. The picture, while a hopeful one, is far from being rosy, for, as the spoakor rocognizes, the resorption cavities originally deseribed by Tomes and De Morgan more than a century ago are still not well undorstood to-day.

Parathyroid hormone seems now to play littlo or no part in the romodelling of compact bone, contrary to the bolief upheld until recently by nost poople. The concept of 'calcifiability' of the organic matrix is gaining support together with tho belief that local acidity, probably caused by the metabolic activity of the osteocytes under the partial control of vitamin $D$ and the parathyroid glands, is rosponsible for the solubilization of bone mineral. 